\title{
Budget impact analysis of surfactant therapy for bronchiolitis in critically ill infants: the Colombian National Health System perspective
}

\author{
Jefferson Antonio Buendía ${ }^{1 *}$ (D) and Diana Guerrero Patiño
}

\begin{abstract}
Background: Severe bronchiolitis requiring mechanical ventilation was associated with an absence of surfactant activity and phosphatidylglycerol, causing airway obstruction in acute bronchiolitis. Exogen surfactant in mechanically ventilated infants decreased duration of stay in the intensive care unit and had favorable effects on oxygenation and carbon dioxide removal. This study aimed to evaluate the budget impact of surfactant therapy for bronchiolitis in critically ill infants in Colombia.

Methods: Budget impact analysis was performed to estimate the economic impact of surfactant therapy (ST) for the treatment of infants with a diagnosis of bronchiolitis, requiring mechanical ventilation. The analysis considered a 4-year time horizon and Colombian National Health System perspective. The model estimated drug costs associated with current scenario using humidified oxygen or adrenaline nebulization, and new scenario adding exogen surfactant. The size of the target population was calculated using epidemiological national data. Univariate one-way sensitivity analyses and scenario analyses were performed.

Results: In the base-case analysis the 4-year costs associated to ST and no-ST were estimated to be US\$55,188,132 and US\$ 55,972,082 respectively, indicating savings for Colombian National Health equal to US\$ 783,950 if ST is adopted for the routine management of patients with bronchiolitis requiring mechanical ventilation. In the oneway sensitivity analysis, only increases in the cost of the surfactant drug and cost or length of stay in the pediatric intensive unit reduce the potential savings of ST.

Conclusion: ST was cost-saving in emergency settings for treating infants with severe bronchiolitis requiring mechanical ventilation. This shift in treatment approach proved to be economically favorable in the Colombian context.
\end{abstract}

Keywords: Surfactant, Colombia, Acute bronchiolitis, Budget impact analysis

\footnotetext{
* Correspondence: jefferson.buendia@gmail.com

${ }^{1}$ Department of Pharmacology and Toxicology, Facultad de Medicina, School

of Medicine, Research Group in Pharmacology and Toxicology (INFARTO),

Universidad de Antioquia, Carrera 51D \#62-29, Medellín, Colombia

Full list of author information is available at the end of the article
}

(c) The Author(s). 2021 Open Access This article is licensed under a Creative Commons Attribution 4.0 International License, which permits use, sharing, adaptation, distribution and reproduction in any medium or format, as long as you give appropriate credit to the original author(s) and the source, provide a link to the Creative Commons licence, and indicate if changes were made. The images or other third party material in this article are included in the article's Creative Commons licence, unless indicated otherwise in a credit line to the material. If material is not included in the article's Creative Commons licence and your intended use is not permitted by statutory regulation or exceeds the permitted use, you will need to obtain permission directly from the copyright holder. To view a copy of this licence, visit http://creativecommons.org/licenses/by/4.0/ The Creative Commons Public Domain Dedication waiver (http://creativecommons.org/publicdomain/zero/1.0/) applies to the data made available in this article, unless otherwise stated in a credit line to the data. 


\section{Background}

Acute Respiratory Distress Syndrome represents a severe form of respiratory failure both for adults and children, with prevalence (range 2.0-12.8\%) and mortality (range $18-27 \%)$ in paediatrics [1]. The case-fatality rate by severe bronchiolitis in the first two years of life is usually 0.5 to $1.5 \%$ in high-income countries and $1.74 \%$ in middle-income countries such as Latin-American $[1,2]$. In Colombia, 260,873 years of life (CI 95\% 208,180-347, 023) were lost due to respiratory sincitial virus bronchiolitis in Colombian children under two years [3], with a high economic burden on the health system [4]. Severe bronchiolitis requiring mechanical ventilation was associated with an absence of surfactant activity and phosphatidylglycerol, causing airway obstruction in acute bronchiolitis [5]. Exogenous surfactant administration appears to change the hemodynamics of the lungs favorably and may be a promising therapy for severe bronchiolitis. A Cochrane systematic review shows that Surfactant used for mechanically ventilated infants and children with bronchiolitis decreased duration of stay in the intensive care unit and had favorable effects on oxygenation and carbon dioxide removal. The pooled mean duration of mechanical ventilation (hours) in the intervention groups was $63.0495 \%$ confidence interval (CI) -130.43 to $4.35 \mathrm{~h}$ ) lower in the three randomized clinical trials included in this review [6]. We hypothesize that TS can reduce the costs of care in patients with severe bronchiolitis., an aspect of vital importance in developing countries with limited health budgets. This study aimed to evaluate the budget impact of surfactant therapy (ST) for bronchiolitis in critically ill infants in Colombia.

\section{Methods}

\section{Analytical framework}

A budget impact analysis was performed to evaluate the potential financial impact deriving from Surfactant therapy in the market of available treatments for bronchiolitis, requiring mechanical ventilation. The analysis considered the perspective of the Colombian National Health System and was conducted over a 4-years' time horizon. A budget impact model (BIM) was developed as a Microsoft Excel $^{\oplus}$ macro-enabled workbook to evaluate the incremental budget impact of Surfactant therapy for treatment of severe bronchiolitis, requiring mechanical ventilation. The incremental budget impact was calculated by subtracting the cost of the new treatment, in which Surfactant therapy (adding to humidified oxygen or adrenaline nebulization) is reimbursed, from the cost of the conventional treatment without Surfactant therapy (only humidified oxygen or adrenaline nebulization). Full details of all assumptions used to develop the base case analysis are provided in Table 1.

\section{Target population}

The target population is represented by infants ( 0 to 12 months of age), term newborn without cardiac or neurological or respiratory or another chronic disease, in pediatric intensive care unit (PICU) with a diagnosis of bronchiolitis, requiring mechanical ventilation. The size of the population for the first year was calculated applying data about the total population under 2 years of age in Colombia [7], incidence of bronchiolitis in Colombia [8], frequency of infant with bronchiolitis requiring mechanical ventilation in Colombia [4, 9]. An annual population growth of $0.8 \%$ was assumed considering the average national growth rate from the period 2015-2019 [7], Table 2.

\section{Intervention}

Exogen Surfactant (intratracheal administration of Surfactant). The information on effectiveness was extracted from the only Cochrane systematic review published which includes information from three controlled clinical trials [6]. In this review, the duration of the intensive care unit (ICU) stay was less in the ST than the control group: MD -3.31, 95\% CI $-6.38-0.25$ days. Serious adverse effects were not reported in these studies. Respect to the drug administration in these trials:

- The Luchetti 1998 included infants on mechanical ventilation for $24 \mathrm{~h}$ without significant improvement of their clinical status (uncorrected congenital heart disease and neuromuscular diseases were excluded by two studies). In this study, porcine surfactant (Curosurf) $50 \mathrm{mg} / \mathrm{kg}$ was administered in two to three doses through an endotracheal tube [10].

- Luchetti 2002 included infants who had mechanical ventilation for at least $12 \mathrm{~h}$ without significant

Table 1 Assumption used to develop the base case analysis

\begin{tabular}{lc}
\hline Assumption & References \\
\hline For all products compliance is considered to be 100\% & Assumption based on the opinion of clinical experts \\
The incidence of adverse events is equal between patients treated with ST and without ST & {$[6]$} \\
The incidence of bronchiolitis is stable over the time horizon & Assumption based on the opinion of clinical experts \\
The incidence of bronchiolitis requiring mechanical ventilation is stable over the time horizon & Assumption based on the opinion of clinical experts \\
The market share for different types of ST are stable over the time horizon & Assumption based on the opinion of clinical experts \\
\hline
\end{tabular}


Table 2 Parameter used in the case base

\begin{tabular}{|c|c|c|c|}
\hline Type of parameter & Base Case value & Range for one-way sensitivity analyses & Reference \\
\hline \multicolumn{4}{|l|}{ Demographics } \\
\hline Population & $2,327,222$ & & {$[7]$} \\
\hline Annual population growth & $0.8 \%$ & & {$[7]$} \\
\hline Pediatric weight & $6.7 \mathrm{~kg}$ & & {$[10-12]$} \\
\hline \multicolumn{4}{|l|}{ Epidemiology } \\
\hline Bronchiolitis incidence & $6.1 \%$ & $4-8 \%$ & {$[8]$} \\
\hline$\%$ bronchiolitis requiring mechanical ventilation & $7.1 \%$ & $2-10 \%$ & {$[4,9]$} \\
\hline \multicolumn{4}{|l|}{ Cost } \\
\hline Survanta® (unit $25 \mathrm{mg}$ ), US\$ & 13 & $10-15$ & [13] \\
\hline Curosurf ${ }^{\oplus}$ (unit $240 \mathrm{mg}$ ), US\$ & 37 & $30-40$ & [13] \\
\hline Infasurf (unit $105 \mathrm{mg}$ ), US\$ & 13 & $10-20$ & [13] \\
\hline \multicolumn{4}{|l|}{ Market Share } \\
\hline Survanta ${ }^{\oplus}$ (unit 25 mg) & $47.3 \%$ & $40-57 \%$ & [14] \\
\hline Curosurf (unit $240 \mathrm{mg}$ ) & $49.2 \%$ & $45-55 \%$ & [14] \\
\hline Infasurf ${ }^{\oplus}$ (unit 105 mg) & $3.4 \%$ & $2-6 \%$ & [14] \\
\hline
\end{tabular}

improvement (uncorrected congenital heart disease and neuromuscular diseases were excluded by two studies). In this study, porcine surfactant (Curosurf) $50 \mathrm{mg} / \mathrm{kg}$ was administered in two aliquots over about five minutes through an endotracheal tube [11].

- The Tibby 2000 study enrolled infants who were ventilated for less than $24 \mathrm{~h}$ with an oxygenation index above five and a ventilation index above 2 (the study did not exclude children with chronic lung disease and prematurity history). In this study, bovine surfactant (Survanta) was administered in two doses $(100 \mathrm{mg} / \mathrm{kg}), 24 \mathrm{~h}$ apart, through an endotracheal tube [12].

According to the Colombian market at the time of the analysis, we have 3 types of surfactant: Survanta ${ }^{\circ}$, Curosurf $^{\oplus}$ and Infasurf ${ }^{\circ}$ have a market shares of $47.35 \%, 49.20$ and $3.4 \%$ respectively [14]. The cost of treatment per patient was calculated:

- the total amount of milligrams per patient/treatment was estimated for each types of surfactant according to the dosing schedules mentioned above, and assuming a patient with average weight of $6.7 \mathrm{~kg}$,

- The cost of each types of surfactant per patient was estimated by multiplying the cost per milligram of each types of surfactant, obtained from the national list of drug costs [13], by the total amount of milligrams estimated per patient/treatment calculated in the previous step

- The final cost of treatment per patient was obtained from the sum of the results of the cost of each type of surfactant per patient multiplied by their market share.

We assumed to progressively gain market sales from surfactant therapy. In the base-case scenario the uptake rate of surfactant therapy was assumed to be $25 \%$, increasing to $25 \%$ each year respectively, according to he estimates of the marketing authorization holder and recommendation of national guidelines for economic evaluations in Colombia [15].

\section{Time horizon}

The time horizon defined was four years. The maximum follow-up time was set to be four years. A longer perspective was not considered relevant for the budget holder following recommendation of national guidelines for economic evaluations in Colombia [15]. All results are depicted cumulatively from 1 to 4 years.

\section{Resource use and cost}

The costs of each outcome defined previously were estimated directly from medical invoices and electronic medical records of 193 infants admitted in tertiary centers in Rionegro, Colombia, with a diagnosis of bronchiolitis, according to the national clinical guidelines of bronchiolitis. This cost and clinical characteristics of these patients were published previously [4]. Brief, the direct costs considered in the analysis include medical consultation at the emergency room, specialist referrals, chest physiotherapy, diagnosis support (laboratory, electrocardiogram, $x$-ray, etc.), medication (oxygen, nebulization, antibiotics, corticosteroids, bronchodilators, etc.), medical devices, hotel services in the intensive care unit, 
and hotel services in the general medical ward. All treatment costs include the administration and preparation costs covered by the treating organization. All adverse events were assumed to be fully reversible and thus not to cause any additional costs to the hospital district. To avoid data errors during medical record abstraction, we used software (Excel $\mathrm{MS}^{\circ}$ ) with automatic calculation functions and error alerts and a review of outliers by the research team. We used US dollars (currency rate in 2019: US\$ $1.00=$ COP\$ 3000) [16] to express all costs in the study. For the valuation of the indirect costs associated with the loss of parents' productivity, the human capital method was used, assuming everyone receives an income of at least a legal minimum wage for formal or informal work. The cost-opportunity of the productivity loss at the workplace and the caregiver was assessed based on the minimum wage without including transportation assistance (US\$229.81 per month). The legal minimum wage approved by the government was taken as a reference and not an average or median wage thereof, given that in Colombia, over $75 \%$ of the population has this value as their income [7]. Because all patients with acute asthma episodes included in this study were children, we assumed that at least one family member accompanied the patient permanently during hospitalization, as pediatric hospitals in the country usually allow only one companion per patient in the hospital. The cost associated with transportation and food (does not include a stay), was assumed to correspond to $50 \%$ of minimum wage per day.

\section{Sensitivity analyses}

The robustness of the base-case was evaluated with oneway sensitivity analyses. The parameters used in the analysis were varied once as detailed in Table 3. Expert opinion and literature data were used to determine ranges of parameters to be tested in the sensitivity analysis. Results of the sensitivity analysis are presented in a

Table 3 Cost (US\$) used in base case and sensitivity analyses

\begin{tabular}{|c|c|c|c|}
\hline Model input & Base case value & SA range for one-way sensitivity analyses & Distribution \\
\hline \multicolumn{4}{|l|}{ Intervention cost } \\
\hline ST per patient day & 203 & $43-352$ & Y (SD:197) \\
\hline \multicolumn{4}{|l|}{ Hospitalization cost } \\
\hline Daily cost in pediatric ward & 48.82 & $47,6450.00$ & $Y(S D: 3,20)$ \\
\hline Hospital length of stay (days) & 5,8 & $4,00-6,01$ & Y (SD:2,03) \\
\hline \multicolumn{4}{|l|}{ PICU related cost } \\
\hline Daily cost in PICU & 327,35 & $326,26-328-43$ & $\gamma(S D: 5,49)$ \\
\hline Reduction in PICU lenght of stay (days) by ST & 3.31 & $0.25-6.38$ & Y (SD:1.8) \\
\hline \multicolumn{4}{|l|}{ Emergency visit prior hospitalization cost } \\
\hline Daily cost of emergency ward & 12,83 & $12,19-13,46$ & $\gamma(S D: 3,20)$ \\
\hline \multicolumn{4}{|l|}{ Direct medical cost per patient-day } \\
\hline Specialist referrals & 10,67 & $10,31-11,01$ & $\gamma(S D: 1,72)$ \\
\hline Chest physiotherapy & 5,15 & $4,90-5,39$ & Y (SD:1,23) \\
\hline Chest radiography & 2,84 & $2,70-2,98$ & $\gamma(S D: 0,73)$ \\
\hline Others diagnostic imaging & 0,01 & $0,0-0,022$ & $\gamma(\mathrm{SD}: 0,08)$ \\
\hline Complete blood cell counts & 1,12 & $1,05-1,17$ & Y (SD:0,28) \\
\hline RSV test & 2,71 & $2,83-3,03$ & $\gamma(S D: 2,72)$ \\
\hline Other laboratory tests & 4,40 & $4,23-4,47$ & $\gamma(S D: 0,37)$ \\
\hline Oxygen & 1,37 & $1,28-1,45$ & $\gamma(S D: 0,41)$ \\
\hline Nebulization & 16,23 & $1,28-1,45$ & Y (SD:4,52) \\
\hline LEV & 1,10 & $1,07-1,13$ & $\gamma(S D: 0,16)$ \\
\hline Antibiotics systemics & 1,21 & $1,11-1,30$ & Y (SD:0,49) \\
\hline Systemic o Inhaled Corticosteroids & 0,08 & $0,0-0,90$ & Y (SD:4,18) \\
\hline Bronchodilators & 0,04 & $0,03-0,04$ & Y (SD:0,02) \\
\hline Other drugs & 0,65 & $0,60-0,68$ & $\gamma(S D: 0,04)$ \\
\hline Medical devices & 10,24 & $9,71-10,76$ & $\gamma(S D: 2,66)$ \\
\hline Indirect cost patient-day & 17,24 & $16.38-18,07$ & Y (SD:4,30) \\
\hline
\end{tabular}


Table 4 Budget impact

\begin{tabular}{lllllll}
\hline & Overall num patients & Num patients treated with ST & Cost ST (US\$) & Cost No ST (US\$) & Savings (US\$) & \% Savings \\
\hline Year $\mathbf{1}$ & 3851 & 963 & 13.747 .011 & 13.824 .148 & 77.138 & $0,56 \%$ \\
year $\mathbf{2}$ & 3882 & 1941 & 13.780 .599 & 13.936 .124 & 155.525 & $1,12 \%$ \\
Year $\mathbf{3}$ & 3914 & 2935 & 13.813 .829 & 14.049 .006 & 235.177 & $1,67 \%$ \\
Year $\mathbf{4}$ & 3946 & 3946 & 13.846 .694 & 14.162 .803 & 316.110 & $2,23 \%$ \\
Total & 15,593 & 9785 & 55.188 .132 & 55.972 .082 & 783.950 & $1,40 \%$ \\
\hline
\end{tabular}

tornado diagram showing the impact on base-case of uncertainty in the parameters used in the model. Microsoft Excel $^{\circ}$ was used in all analyses.

\section{Results}

\section{Base-case results}

In the base-case analysis the 4-year costs associated to ST and no-ST were estimated to be US\$ 55.188.132 and US\$ 55.972.082 respectively, indicating savings for Colombian National Health equal to US\% 783.950 if ST is adopted for the routine management of patients with bronchiolitis requiring mechanical ventilation (Table 4). The savings by ST increased over the years due to the greater number of patients progressively receiving ST and savings of cost of PICU, Fig. 1.

The Tornado diagram shows the results of one-way sensitivity analysis, Fig. 2.Expected cost of ST was always lower than no ST except in three variables: drug cost of surfactant and daily cost in PICU and PICU length of stay, Fig. 2. A increase in the total cost of treatment with ST higher than U\$257 per patient, resulted in expected cost per patient in ST scenario more elevated than no ST scenario (US\$ 259 vs US\$ 254), see Fig. 3. When the PICU length of stay was higher than 9.4 days, also the expected cost per patient in ST scenario was higher than no ST and if the daily cost in PICU was higher than US\$ 266 the expected cost per patient in ST scenario was higher than no ST, losing also in both cases the savings generated by the population by the use of ST. In scenarios where the expected cost per patient or the PICU length of stay are lower, ST will be cost-saving.

\section{Discussion}

Our study suggests that ST is a cost-saving for the treatment of infant with severe bronchiolitis requiring mechanical ventilation. The therapy only with humidified oxygen or adrenaline nebulization without ST proved to be the most expensive therapy, being associated with the highest total cost. Treatment with ST over four years was cost-saving thanks to the fewer cost of mechanical ventilation being observed with this regimen. Compared with the current therapy without ST, the alternative treatment with MS provided total cost saving US $\$ 771.377$..

Previous publications have shown that bronchiolitis has a relevant impact on healthcare resources consumption and related expenditures, especially in severe cases, and any intervention that reduces the burden of disease and costs is highly appropriate to any health system [3, $4,9,17]$. Surfactant is the therapy with the highest level of expectations due to a positive effect in PICU length of stay, but still a few evidence in endpoints such as mortality. A recent study shows that the use of porcine Surfactant improves oxygenation, $\mathrm{P} / \mathrm{F}$ ratio, and $\mathrm{pH}$ in a population of children with moderate or severe pediatric acute respiratory distress syndrome caused by multiple diseases [18]. In an infant with severe RSV infection, the administration in mechanically ventilated infants with acute respiratory failure due to RSV bronchiolitis

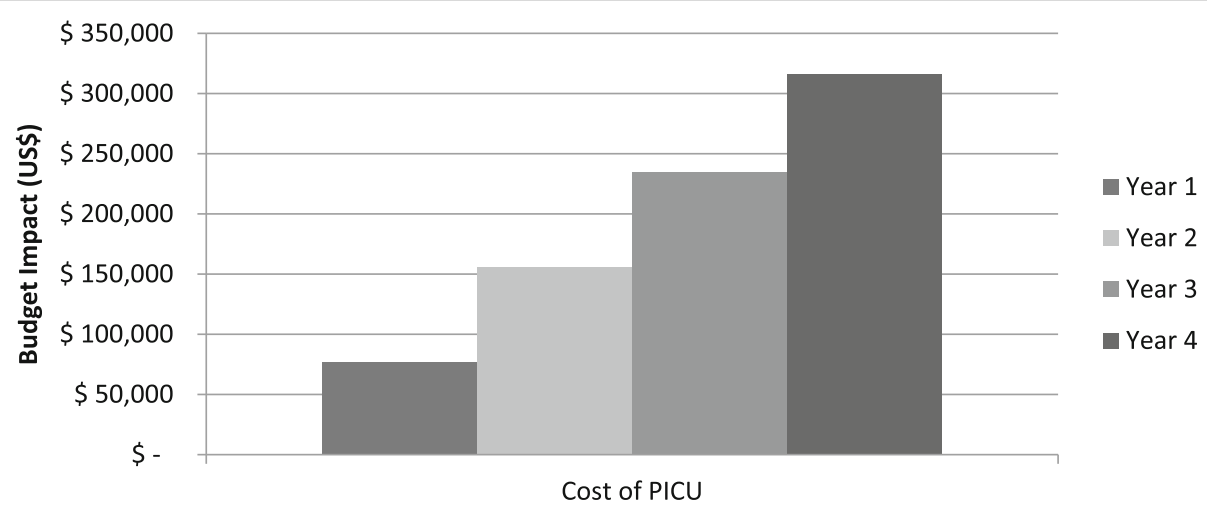

Fig. 1 Savings in pediatric intensive critical unit (PICU) cost 


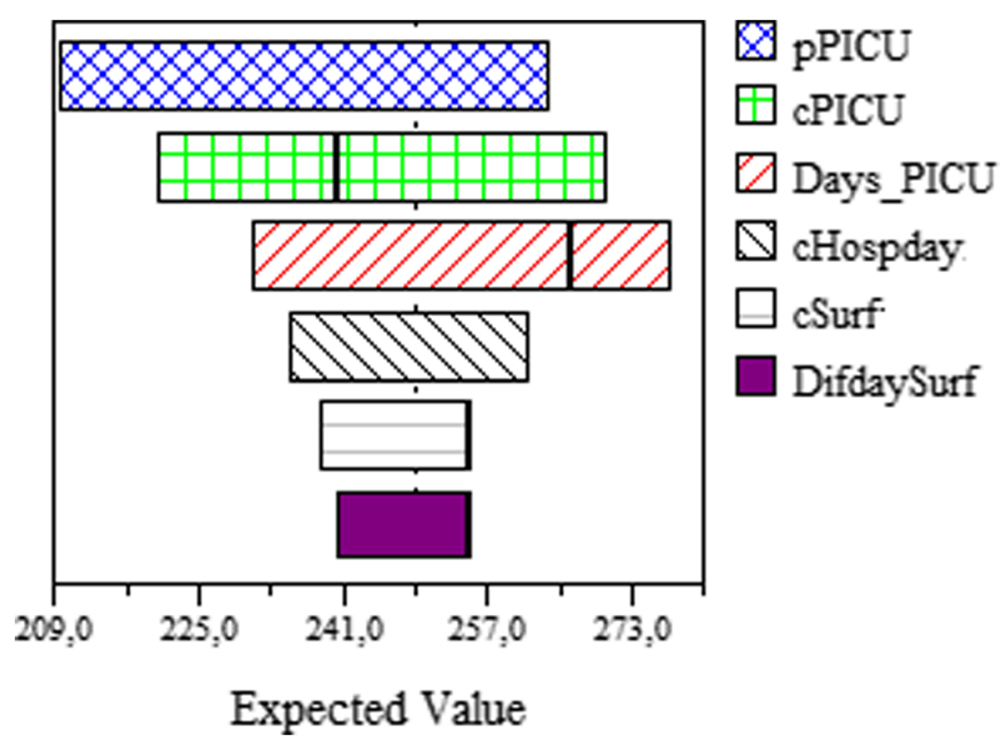

Fig. 2 Tornado diagram

improves gas exchange and respiratory and shortens the duration of mechanical ventilation and PICU stay compared with control [6]. Despite that, the duration of mechanical ventilation was no different in the surfactant group compared to the control group (mean difference (MD) $-63.04 \mathrm{~h}, 95 \%$ confidence interval (CI) -130.43 to 4.35), there was a trend towards beneficial effects of Surfactant [6]. It is possible that with more randomized controlled trials, this effect could be reached. Also, this systematic review reported that no adverse hemodynamic effects (no significant change in heart rate and blood pressure) and no complications were noted in the clinical trials included in this publication. We can conclude, the ST would be a therapeutic option safe, with positive clinical effects in the PICU length of stay and in health cost [19].

The total health spending for communicable diseases in Colombia ranges from $\$ 70$ to $\$ 80$ million annually [20]. If this drug is adopted within the clinical practice guidelines, of the total mentioned above, almost 1

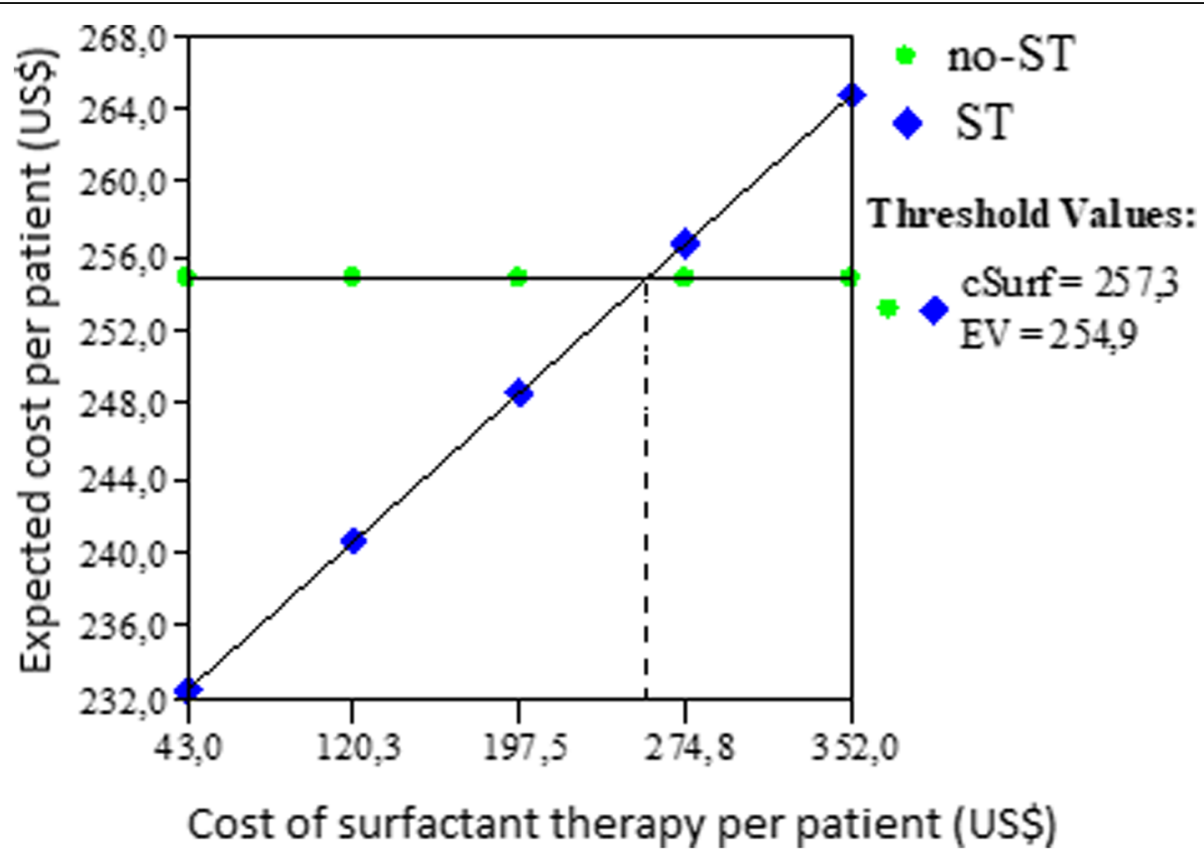

Fig. 3 Threshold analysis of cost of surfactant therapy 
million dollars could be saved annually;. Otherwise, the ST was always the cost-saving strategy in all ranges of probabilities of requiring mechanical ventilation evaluated. A relevant result was to find a drug cost of the ST per patient at which this therapy does not cost-saving. This threshold (US\$ 257) can be used as a reference for the control and regulation of prices in the country. Show evidence related to the economic impact this drug is essential to policy makers and physician [21] especially in developing countries where economic evaluation of drugs and medical devices in pediatric patients are increasing [17, 22-25].

Our study has some limitations. We used retrospective data reported in a previously cost-effectiveness study, and this information does not exclude the possibility that medical invoices were incomplete or missing data. This study reported that several measures were employed to ensure data accuracy, including software with automatic calculation functions and error alerts and a review of outliers by the research team. Another limitation in the design was to the assumption of complete adherence of this therapy, which can reduce the budget impact of ST. A clinically significant reduction can be seen with outpatient medications, but with medications in critically ill patients, high adherence can be expected.

In conclusion, ST was cost-saving in emergency settings for treating infants with severe bronchiolitis requiring mechanical ventilation. This shift in treatment approach proved to be economically favorable, reducing the cost of hospitalization and mechanical ventilation. This evidence can be used by decision-makers in our country to improve clinical practice guidelines and should be replicated to validate their results in other middle-income countries.

\section{Abbreviations}

ST: Surfactant therapy; no-ST: Control or non-surfactant therapy; BIM: Budget impact model; PICU: Pediatric intensive care unit

\section{Acknowledgments}

None to declare.

\section{Authors' contributions}

All the authors (JAB, DGP) contributed in the same way from conception of the work to the publication of results. All Authors read and approved the manuscript.

\section{Funding}

Own fundings.

\section{Availability of data and materials}

The raw data supporting your findings can be request to CIEMTO (http:// ciemto.medicinaudea.co/).

\section{Declarations}

\section{Ethics approval and consent to participate}

This study was approved by the Institutional Review Board of University of Antioquia (2015-4690).
Consent for publication

Not Applicable.

\section{Competing interests}

The authors declare that they have no competing interests.

\section{Author details}

'Department of Pharmacology and Toxicology, Facultad de Medicina, School of Medicine, Research Group in Pharmacology and Toxicology (INFARTO), Universidad de Antioquia, Carrera 51D \#62-29, Medellín, Colombia. ${ }^{2}$ Hospital Infantil Concejo de Medellin, Medellin, Colombia.

Received: 2 January 2021 Accepted: 3 April 2021

Published online: 13 April 2021

\section{References}

1. Khemani RG, Smith LS, Zimmerman JJ, Erickson S, Pediatric acute lung injury consensus conference $\mathrm{G}$. Pediatric acute respiratory distress syndrome: definition, incidence, and epidemiology: proceedings from the pediatric acute lung injury consensus conference. Pediatr Crit Care Med. 2015;16(5 Suppl 1):S23-40. https://doi.org/10.1097/PCC.0000000000000432.

2. Word Bank The Word Bank In Middle Income Countries. Available from: https://www.worldbank.org/en/country/mic. Accessed 07 Apr 2021.

3. Villamil JPS, Polack FP, Buendía JA. Disability-adjusted life years for respiratory syncytial virus in children under 2 years. BMC Public Health. 2020;20(1):1679. https://doi.org/10.1186/s12889-020-09796-x.

4. Buendia JA, Patino DG. Costs of Respiratory Syncytial Virus Hospitalizations in Colombia. Pharmacoecon Open. 2020.

5. Skelton R, Holland P, Darowski M, Chetcuti PA, Morgan LW, Harwood JL. Abnormal surfactant composition and activity in severe bronchiolitis. Acta Paediatr. 1999;88(9):942-6. https://doi.org/10.1111/j.1651-2227.1999.tb00186.

6. Jat KR, Chawla D. Surfactant therapy for bronchiolitis in critically ill infants. Cochrane Database Syst Rev. 2015;8:CD009194.

7. Departamento, Nacional, (DANE) DE. Archivo Nacional de Datos 2019 [Available from: https://sitios.dane.gov.co/anda-index/. Accessed $07 \mathrm{Apr}$ 2021.

8. Instituto, Nacional, Salud d. Infeccion respiratoria aguda en Colombia 2017 [05/07/2019]. Available from: https://www.ins.gov.co/buscador-eventos/ Informesdeevento/Informe\%20IRA\%20Final\%202017.pdf. Accessed 07 Apr 2021.

9. Rodriguez-Martinez CE, Sossa-Briceno MP, Castro-Rodriguez JA. Direct medical costs of RSV-related bronchiolitis hospitalizations in a middleincome tropical country. Allergol Immunopathol (Madr). 2019;48(1):56-61.

10. Luchetti M, Casiraghi G, Valsecchi R, Galassini E, Marraro G. Porcine-derived surfactant treatment of severe bronchiolitis. Acta Anaesthesiol Scand. 1998; 42(7):805-10. https://doi.org/10.1111/j.1399-6576.1998.tb05326.x.

11. Luchetti M, Ferrero F, Gallini C, Natale A, Pigna A, Tortorolo L, et al. Multicenter, randomized, controlled study of porcine surfactant in severe respiratory syncytial virus-induced respiratory failure. Pediatr Crit Care Med. 2002;3(3):261-8. https://doi.org/10.1097/00130478-200207000-00011.

12. Tibby SM, Hatherill M, Wright SM, Wilson P, Postle AD, Murdoch IA. Exogenous surfactant supplementation in infants with respiratory syncytial virus bronchiolitis. Am J Respir Crit Care Med. 2000;162(4 Pt 1):1251-6. https://doi.org/10.1164/ajrccm.162.4.9909004.

13. MinSalud. Termometro de precios de medicamentos 2014 [Available from: https://www.minsalud.gov.co/salud/MT/Paginas/termometro-de-precios.a spx. Accessed 07 Apr 2021

14. MinSalud. Sistema Integral de informacion de la proteccion social 2019 [Available from: https://web.sispro.gov.co/WebPublico/Consultas/Consulta rCNPMCadenaComercializacionCircu2yPA_028_2_2.aspx. Accessed 07 Apr 2021.

15. Instituto de Evaluación Tecnológica en Salud. Manual para la elaboración de análisis de impacto presupuestal. Bogotá D.C: IETS; 2014.

16. la Bd, Republica. Tasa Representativa del Mercado (TRM - Peso por dólar) 2019 [cited 2020. Available from: https://www.banrep.gov.co/es/estadisticas/ trm. Accessed 07 Apr 2021.

17. Buendia JA, Acuna-Cordero R. The cost-effectiveness of hypertonic saline inhalations for infant bronchiolitis. BMC Health Serv Res. 2020;20(1):1001. https://doi.org/10.1186/s12913-020-05814-1. 
18. Wolfler A, Piastra M, Amigoni A, Santuz P, Gitto E, Rossetti E, et al. A shared protocol for porcine surfactant use in pediatric acute respiratory distress syndrome: a feasibility study. BMC Pediatr. 2019;19(1):203. https://doi.org/1 0.1186/s12887-019-1579-3.

19. Sullivan SD, Mauskopf JA, Augustovski F, Jaime Caro J, Lee KM, Minchin M, et al. Budget impact analysis-principles of good practice: report of the ISPOR 2012 budget impact analysis good practice II task force. Value Health. 2014;17(1):5-14. https://doi.org/10.1016/j.jval.2013.08.2291.

20. MinSalud. Estructura del gasto en Salud Pública en Colombia 2018

[Available from: https:/www.minsalud.gov.co/sites/rid/Lists/BibliotecaDigita I/RIDE/DE/PES/estructura-gasto-salud-publica-colombia.pdf. Accessed 07 Apr 2021.

21. Buendia JA, Zuluaga AF. Physicians insight about adverse drug reaction to frequently used medication groups in Bogota (Colombia). Biomedica. 2014; 34(3):403-8. https://doi.org/10.1590/50120-41572014000300010

22. Buendia JA, Sanchez-Villamil JP, Urman G. Cost-effectiveness of diagnostic strategies of severe bacterial infection in infants with fever without a source. Biomedica. 2016;36(3):406-14. https://doi.org/10.7705/biomedica.v36i3.2718.

23. Antonio Buendia J, Colantonio L. Costo-Efectividad de la Proteina C Reactiva, Procalcitonina y Escala de Rochester: Tres Estrategias Diagnosticas para la Identificacion de Infeccion Bacteriana Severa en Lactantes Febriles sin Foco. Value Health Reg Issues. 2013;2(3):375-80. https://doi.org/10.1016/j. vhri.2013.10.001

24. Buendia JA, Acuna-Cordero R, Rodriquez-Martinez CE. The cost-utility of intravenous magnesium sulfate for treating asthma exacerbations in children. Pediatr Pulmonol. 2020;55(10):2610-6. https://doi.org/10.1002/ ppul.25024

25. Buendia JA, Talamoni HL. Cost-utility of use of sputum eosinophil counts to guide management in children with asthma. J Asthma. 2020:1-7. https:// doi.org/10.1080/02770903.2020.1830412

\section{Publisher's Note}

Springer Nature remains neutral with regard to jurisdictional claims in published maps and institutional affiliations.

Ready to submit your research? Choose BMC and benefit from:

- fast, convenient online submission

- thorough peer review by experienced researchers in your field

- rapid publication on acceptance

- support for research data, including large and complex data types

- gold Open Access which fosters wider collaboration and increased citations

- maximum visibility for your research: over $100 \mathrm{M}$ website views per year

At $\mathrm{BMC}$, research is always in progress.

Learn more biomedcentral.com/submissions 